\title{
REVIEW \\ Outline of the Comprehensive Soil Classification System of Japan - First Approximation
}

\author{
Hiroshi OBARA*, Yuji MAEJIMA, Kazunori KOHYAMA, \\ Toshiaki OHKURA and Yusuke TAKATA \\ Natural Resources Inventory Center, National Institute for Agro-Environmental Sciences (Tsukuba , \\ Ibaraki 305-8604, Japan)
}

\begin{abstract}
The characteristics of Japanese soil were developed by wide paddy field farming, the influence of volcanic ash on soil, and a perudic moisture regime under temperate climatic conditions. Major soil classifications in Japan have developed in line with public work projects and soils in Japan have tended to be classified independently depending on the land use, such as cultivated area, forest, and so forth. Consequently, there is no available soil map drawn with a single framework of soil classification on a practical map scale, which hampers the progress of environmental studies such as watershed-level nutrient cycling, carbon sequestration and so on. In response, we published the Comprehensive Soil Classification System of Japan - First Approximation; a more practical system that enables the nationwide classification of soils. In it, we defined the following categories: soil great group, soil group, soil subgroup, and soil series group, determined by dichotomous keys. The proposed system contains 27 soil groups, 116 soil subgroups and 381 soil series groups. Setting these 4 category levels renders the system usable for both general outlines and detailed descriptions, and to create soil maps and soil information on various scales.
\end{abstract}

Discipline: Soils, fertilizers and plant nutrition

Additional key words: Ando soils, Paddy soils, Upland soils

\section{Introduction}

Soil is a natural body that covers the thin surface layer of the Earth. It provides nutrients and water to plants and supports plant bodies. Soil is also a living space and habitat for animals and microorganisms. Although soils have common general properties, their figure and properties vary considerably depending on the soil forming factors. Soils are the end product of the collective influence of climate, relief, organisms, parent materials and time. Understanding soil varieties and classifying them while keeping their different characteristics in mind is crucial to recognizing the environment, managing soils and keeping land sustainable.

In Japan, these differences in soils were recognized and old documents of agricultural guidance from the Edo era $(1600-1868)$ have emerged. More recently, the first national soil survey program was launched in the $1870 \mathrm{~s}$, using a European agro-geological soil classification introduced by Dr. Fesca from Germany, following which certain soil survey programs have been carried out for agricultural land, forest land, and other land use to date. Soil classification systems were also developed to order data and publish survey reports, referring to the development of soil classification systems overseas and international organizations such as FAO and IUSS. The characteristics of Japanese soil emerged through wide paddy field farming, the influence of volcanic ash on soil, and a perudic moisture regime under temperate climatic conditions. The soil classifications of Japan were developed to identify soils with peculiar characteristics under those conditions, and group soils in meaningful ways for agricultural, and forestry production.

In this paper, we would like to introduce soil classification of major soils in Japan and provide an outline of the latest soil classification; namely "the Comprehensive Soil Classification System of Japan - First Approximation".

\section{General view of the soil classification of major soils in Japan}

The soil classification in Japan has proactively developed in three fields, namely paddy soils, volcanic ash soils,

*Corresponding author: e-mail obara@affrc.go.jp

Received 12 December 2013; accepted 10 November 2014. 
and upland soils, which are hardly affected by volcanic ash or not at all.

(1) Soils of lowland paddy fields

Paddy fields have been widely distributed in alluvial plains and have occupied certain upland and mountainous areas in Japan, while rice has remained the most important cereal crop in Japan. Consequently, many studies have been conducted on paddy soils (Kyuma 2004), and unique soil classifications for paddy soils in Japan have emerged.

Paddy soils are submerged, either artificially or naturally, for at least three to four months a year. During most of this period, the surface plow layer remains under a reduced condition, which means the paddy soils have unique characteristics, compared with upland soils. However these unique characteristics were not recognized in early soil classification systems. For the alluvial plain, on the first soil survey program; i.e. agro-geological classification (Fesca et al. 1882), paddy soils were classified as combinations of alluvial sediment and soil texture. A scientific soil classification was adopted to alluvial soils by Kamoshita (1940). He introduced ground water soil types (a hydro-sequence system) developed in Germany to make a soil survey report. The ground water soil types, i.e. Bog soil, Half-bog soil, Meadow soil, Gray lowland soils and Brown lowland soil, has been fundamentals of Japanese soil classification for naturally developed alluvial soils, but no unique characteristics deriving from the submerging period have been introduced to the soil classification system. The first soil classification that referred to characteristics derived from the continuous submerged condition of the plow layer of paddy soil, was published by Uchiyama (1949). In his classification, it was recognized that the aquic condition derived by continuous irrigation in well-drained paddy fields promoted the development of peculiar soil profiles, i.e. iron and manganese illuvial horizons in subsurface soils (Fig. 1). Following Uchiyama's classification, some soil classification was proposed for paddy soils (Kanno 1957, Yamazaki 1960, Matsui et al. 1961). The characteristics of the artificially developed aquic soils in paddy fields were studied in detail and a comprehensive classification framework including ground water (natural) aquic and artificial aquic was proposed by Mitsuchi (1974). This framework was adapted to later soil classification systems in Japan as well as some part of the diagnostic horizon or properties adapted to the USDA soil taxonomy (1990) and World Reference Base for soil resources (WRB 1998). On the ground water aquic soils, the relationship between ground water dynamics and the diagnostic horizon (e.g. gley horizon, mottled horizon) was clarified (Hamazaki 1993).

(2) Soils developed from volcanic ash; Ando soils

There are many active volcanos in Japan, and volcanic ash has covered wide areas of land. Soils having developed from volcanic ash have distinct properties such as A horizon, rich in organic carbon and with high phosphate fixation potential, friable consistence and light bulk density. Those varieties were generally known as volcanic ash soils, and the traditional name 'Kurobokudo' has been used in many soil classification systems in Japan. After World War II, a reconnaissance soil survey of Japan was carried out by the Natural Resources section of the Supreme Commander for the Allied Powers. In the survey report, soils that derived from volcanic ash were designated "Ando soils", whereupon "Ando" was used to indicate volcanic ash soils in many global soil classification systems.

The widely accepted concept of Ando soils in Japan was as a reference to volcanic ash-derived soils with high phosphate absorption coefficient, low bulk density and friable consistence (Cultivated soil Classification Committee 1995). These properties are mainly attributable to the presence of significant allophane, imogolite, ferrihydrite, or aluminum-humus complexes in soils (Soil Survey Staff 1999).

In Japan, many studies have been conducted on Ando soils (Wada et al. 1986). Regarding the black A horizon, the type of humic acid was actively studied and a melanic index usable to separate black A horizon form relatively brown-colored A horizon was proposed by Honna (1988). The melanic index was also adapted to define the melanic horizon in WRB and USDA soil taxonomy.

Amorphous clay mineral, e.g. Allophane, had been considered a dominant component of clay minerals of Ando soils. However some studies (Wada 1980, Kato 1984, Shoji et al. 1985) indicated the existence of some Ando soils with clay fractions dominated by $2: 1$ and $2: 1: 1$ minerals and their intergrades. Those Ando soils with 2:1 clay minerals have an important characteristic, namely their high content of $\mathrm{KCl}$ extractable $\mathrm{Al}$, which is toxic to plant roots (Saigusa et al. 1980). The difference between the amorphous clay and 2:1 clay types was important; not only for agronomy

Lowland Paddy Soil
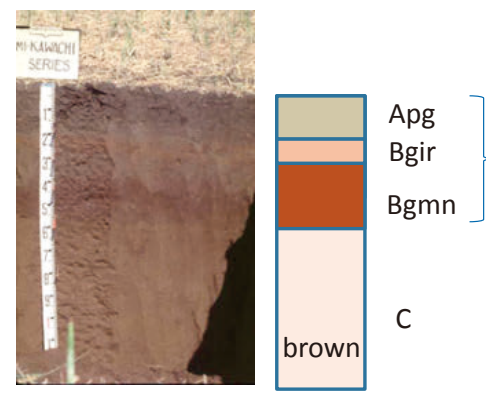

Epiaquic derived from irrigated water

Apg: Puddled layer

Bgir: Iron illuviated horizon

Bgmn: Manganese illuviated horizon

Fig. 1. An Example of Soils Developed by Artificial Hydromorphism 
also the soil genetic process. Accordingly, those two types were separated in a higher categorical level in the Japanese soil classification from 1986 (first Committee for Soil Classification and Nomenclature). The high exchangable Al characteristics of 2:1 type Andosol were adapted in the "alic" prefix of the WRB system and the "alic" subgroup of the USDA soil taxonomy.

(3) Upland Soils (non-volcanic origin)

Soil colors of the subsurface horizon have been used for soil names in Japan, while in alluvial soils, soil colors indicate the duration and degree of the layer-reducing conditions. For example, gley indicates permanently reducing conditions, gray indicates seasonal reducing conditions, and brown indicates no or slight reducing conditions. Yellow, red, and dark-red colors were used to designate upland soil names and the differences among them have been continuously studied. The basic concepts of those colors are as follows: Brown indicates the existence of iron oxyhydroxides that are isolated from their parent materials. Yellow indicates relatively crystallized iron oxides than brown. Red indicates highly crystallized iron oxides in a warmer climate than yellow. Dark-red indicates a darker color, a greater iron oxide content, or the existence of other dark-colored materials such as manganese and chromium oxides.

In Japan, red- and yellow-colored soils are widely distributed in the subtropical to warm-temperate zone, and designated as so-called Red-Yellow soils. Two theories exist with regard to the genesis of red-colored soils. One is the zonal red soil theory, whereby Red soil was considered to have formed under present climatic conditions. Another is the paleo red soil theory, whereby Red soil was deemed a relic of paleosols in a past geological age warmer than at present. The existence of paleo-Red soils in Japan was first reported by Ohmasa et al. (1955). Subsequently, Matsui and Kato (1962) proved that paleo-Red soils were distributed in southwest as well as northwest Japan. Moreover, Matsui (1964) proposed the newly established "Yellow-brown forest soil" as a zonal soil type of southwest Japan at present, whereupon Nagatsuka (1975) revealed the distribution patterns of Red- and Yellow-brown forest soils, and also clarified their morphological features, physico-chemical and mineralogical properties. Moreover, it was clearly shown that three types, namely Red soils, Yellow-Brown Forest soils, and Brown Forest soils, were quantitatively discriminated in terms of the degree of crystallization of free iron oxides (Nagatsuka 1975). Conversely, several different views have been proposed with regard to the age of Red soils of Japan, probably between late Pliocene and early Pleistocene. For instance, Akagi et al. (2003) estimated the formation period of paleo-Red soils in southern Kyushu, and clarified that paleo-Red soils were formed from 400-500 to 110-130 ka. Nagatsuka and Maejima
(2001) also estimated the absolute age of soils on the raised coral limestone terrace, and stated that it would take around $125 \mathrm{ka}$ for Red-Yellow soils to develop on coral limestone in the humid subtropical rainforest climate region. However, Araki (1993) suggested that it was impossible to distinguish between paleo-Red soils and recent Red soils because the properties of Red-Yellow soils changed continuously depending on whether the zone concerned was tropical, subtropical or temperate. For instance, the cation exchange capacities (CEC) of red-colored B horizons of northeast Japan are relatively high (usually exceeding $25 \mathrm{cmolc} \mathrm{kg-}$ 1 clay), while those B horizons are in the early stage of the weathering process (Araki 1993).

According to the Classification of Forest Soil in Japan (1975), "Brown forest soil”, as proposed by Ohmasa (1951), is widely distributed in mountainous and hilly regions under the cool and temperate zone in Japan, and with a browncolored B horizon. The Brown forest soils were subdivided in detail based on unique criteria; reflecting soil moisture conditions that correlate well to the forest types and growth of the Japanese cedar, and Japanese cypress. In this system, the udic moisture regime (USDA) was subdivided into six subgroups, i.e. BA: Dry brown forest soil (loose granular structure type), BB: Dry brown forest soil (granular and nutty structure type), BC: Weakly dried brown forest soil, BD: Moderately moist brown forest soil, BE: Slightly wetted brown forest soil, and BF: Wet brown forest soil. However, Japan belongs to the circum-Pacific orogenic zone and has many active volcanoes. Accordingly, brown Brown forest soils in mountainous areas or on hillsides are more or less affected by volcanic ash. Recently, Imaya (2010) proposed an advanced classification of Brown forest soils with the degree of volcanic ash additions.

Correlation with Soil Taxonomy, the existence of clay illuvial horizon in upland soils of Japan was studied based on certain cases from the 1970s. In some Red-Yellow soils, clay films were observed in the soil thin section, although many such soils with clay films had some aquic features such as iron mottling or a grayed matrix. The existence of clay films in moist soil remained unclear, even if the soils were old and significantly weathered. The absence of clay films in the B horizon of relatively old soil, was supposed to be effected by perudic conditions of Japan. These conditions mean there are no significant changes in soil moisture conditions year-round, except for the thin surface layer. The clay particles of surface soils tend to be difficult to disperse because of the humus-rich and low $\mathrm{pH}$ conditions, meaning the migration of clay from surface to subsurface horizon by water is relatively unclear in those soils. Accordingly, the existence of an argillic horizon was not adopted in Japanese soil classification systems until 2002. However, the argic horizon adopted in WRB covered a wider range of the clayey B horizon than the argillic horizon of Soil Taxonomy. 
Moreover, the existence of clay accumulated B horizons was clarified by certain micromophological studies in the 1990s. Accordingly, the soil classification committee of Japanese Pedologist (2002) adopted the criteria of an argic horizon to separate Red-Yellow soils from other upland soils (The Fourth Committee for Soil Classification and Nomenclature; The Japanese Society of Pedology 2003).

\section{Outline of the Comprehensive Soil Classification System of Japan - First Approximation}

Major soil classifications in Japan have developed in line with public work projects, while soils in Japan have tended to be classified independently for different land use, such as cultivated area (paddy field, upland field), forest, and so forth. Consequently, there is no available soil map drawn with a single framework of soil classification on a practical map scale, which hampers the progress of environmental studies such as watershed-level nutrient cycling, carbon sequestration and so on. To find a solution, the Japanese Society of Pedology developed a new soil classification system, which was published as the Unified Soil Classification System of Japan - 2nd Approximation (2002). However, since this classification system lacked lower attribute categories such as soil texture and the presence or absence of gravel layers, it was insufficient to provide practical soil mapping units which can provide useful information to environmental issues, such as environmental pollution, global warming, etc. In response, we propose the Comprehensive Soil Classification System of Japan - First Approximation as a more practical system, allowing the nationwide classification of soils.

We applied the following four basic policies in drafting this proposed classification system: (1) integrating the Classification of Cultivated Soils in Japan - Third Approximation with the Unified Soil Classification System of Japan - 2nd Approximation (2002) (The Fourth Committee for Soil Classification and Nomenclature The Japanese Society of Pedology 2003); (2) basing it on the Classification of Cultivated Soils in Japan-Third Approximation (Cultivated soil Classification Committee 1995) as far as possible to facilitate the continued use of existing data and knowledge; (3) limiting laboratory analysis to obtain clas- sification criteria and facilitate classification for users; (4) validating the system using available data, and not introducing new taxonomic units and differentiating criteria unless absolutely necessary.

In this proposed system, we defined the following categories: soil great group, soil group, soil subgroup, and soil series group, as determined by dichotomous keys. These keys comprise diagnostic horizons, diagnostic properties, and diagnostic materials and are defined as objectively and quantitatively as possible. Identifying a soil involves determining the presence or absence of diagnostic horizons or characteristics in the soil profile, and the position in which they appear in the profile. The soil great group has ten great groups: Man-made soils, Organic soils, Podzols, Andosols, Dark Red soils, Lowland soils, Red-Yellow soils, Stagnic soils, Brown Forest soils, and Regosols. Each soil great group is further subdivided into 1-6 soil groups according to its moisture regime, parent materials, and other soil formation factors. Soil subgroups are lower categories, ranging from soils with properties intermediate to the different soil groups to those that are typical of a particular soil group. Soil subgroups are further divided into soil series groups according to differences in soil texture, the presence or absence of a gravel layer, and other characteristics. Consequently, this proposed system contains 27 soil groups, 116 soil subgroups and 381 soil series groups (Table 1). Setting these 4 category levels renders the system usable for both general outlines and detailed descriptions, and allows soil maps and soil information on various scales to be created.

(1) Characterization of Soil Great Groups and Soil groups

Table 2 shows the list of great soil groups and soil groups of the Comprehensive Soil Classification System of Japan - First 1st Approximation with reference to WRB and Soil Taxonomy.

A Man-made soils

Man-made soils are defined as "soils greatly altered by artificially stacking artifacts or qualitatively different soil materials $35 \mathrm{~cm}$ thick or more". Those soils will be found in urban areas, reclaimed lakes and shallow seas by filling with soil materials of terraces, hills and mountains. This soil great group comprises two soil groups:

A1 Artifactual soils

Table 1. Categories of Comprehensive Soil Classification System of Japan First Approximation

\begin{tabular}{lcl}
\hline \hline Categories & Number of items & examples \\
\hline Great soil groups & 10 & Andosols \\
Soil groups & 27 & Allophanic Andosols \\
Soil subgroups & 116 & Cumulic Allophanic Andosols \\
$\quad$ Soil series groups & 381 & High-humic Cumulic Allophanic Andosols \\
\hline
\end{tabular}


Table 2. Correlation of Proposed System with WRB and USDA System.

Comprehensive Soil Classification System of Japan First Approximation (2011)

Soil Taxonomy (USDA, 2010)

Great Soil groups

Soil Groups

A. Man-made soils

Artifactual soils

(Udorthents)

Reformed soils

B. Organic soil group

Peat soils

C. Podzols

Podzols

D.Andosols

Regosolic Andosols

Gleyed Andosols

Wet Andosols

Fuluvic Andosols

Non-allophanic Andosols

Allophanic Andosols

E. Dark Red soils

Calcaric Dark Red soils

Dystric Dark Red soils

Eutric Dark Red soils

F. Lowland soils

Lowland Paddy soils

Gley Lowland soils

Gray Lowland soils

Brown Lowland soils

Regosolic Lowland soils

G. Red-Yellow soils

$$
\begin{aligned}
& \text { Argic Red-Yellow soils } \\
& \text { Cambic Red-Yellow soils }
\end{aligned}
$$

H. Stagnic soils

Stagnogley soils

Pseudogley soils

I. Brown Forest soils

Brown Forest soils

J. Regosols

Volcanogenous Regosols

Sandy Regosols

Lithosols

Terrestrial Regosols
(Udorthents)

Histosols

Histosols

Spodosols

Andisols

Vitrands, Aquands

Aquands

Aquands

Fluvudands

Alic Hapludands

Melanudands

Udands

Udalfs, Udepts

Udults, Udepts

Udalfs, Udepts

Anthraquic Eutrudepts

Aeric Epiaquepts

Aquents, Aquepts

Aquepts, Aquents

Udifluvents, Psamments

Udifluvents, Psamments

Udults

Udepts

Aquepts, Aqults, Aquents

Epiaquepts, Endoaquepts, Endoaquents

Aquepts, Aquults

Udepts

Orthents

Udipsamments

Udorthents, Rendolls

Udorthents
World Reference Base for Soil

Resources (2006)
Technosols

Regosols (Transportic)

Histosols

Histosols

Podzols

Podzols

Andosols

Vitric Andosols

Gleyic Silandic Andosols

Gleyic Aluandic Andosols

Gleyic Silandic Andosols

Gleyic Aluandic Andosols

Fluvic Silandic Andosols

Fluvic Aluandic Andosols

Aluandic Andosols

Silandic Andosols

Luvisols, Cambisols

Alisols, Acrisols, Cambisols

Luvisols, Cambisols

Fluvisols, Anthrosols

Fluvic Hydragric Anthrosols

Gleyic Fluvisols

Gleyic Fluvisols

Haplic Fluvisols

Haplic Fluvisols

Alisols, Acrisols

Cambisols

Gleysols, Stagnosols, Anthrosols

Gleysols, Anthrosols

Stagnosols, Gleysols

Cambisols, Stagnosols

Regosols (Tephric)

Arenosols

Leptosols

Regosols, Leptosols, Phaeozems 
Artifactual soils are a new soil group; combining soils whose properties and pedogenesis are dominated by their technical origin and which contain a significant amount of artifacts (household waste, plastics, landfills, sludge, cinders, mine spoils and ashes). The total thickness of layers containing artifacts more than $20 \%$ should be $25 \mathrm{~cm}$ or more within $50 \mathrm{~cm}$ of the mineral soil surface.

A2 Reformed soils

Reformed soils are defined as "soils greatly altered by artificially stacking qualitatively different soil materials $35 \mathrm{~cm}$ thick or more".

B Organic soil group

"Thick accumulated debris of hydrophile plants which remain due to waterlogged anaerobic conditions". These soils are mainly found in the back marsh of natural levees and coastal sand dunes. Organic soils are defined as "soils in which the cumulative thickness of the organic layers (with more than $20 \%$ organic matter and some peat) is $25 \mathrm{~cm}$ or more within $50 \mathrm{~cm}$ of the soil surface". This soil great group has only one soil group, "Peat soils".

\section{Podzols}

Podzols are "soils with the horizon sequence of bleached (E) horizon/humus and/or iron accumulation (Bh and/or Bs) horizons". These soils mainly occur in the mountains and hills of the Hokkaido, Tohoku and Chubu regions, but are also partly found in the coastal sand dunes of Hokkaido region. This soil great group has only one soil group, "Podzols"

D Andosols

The widely accepted concept of Andosols is volcanic ash-derived soils with high phosphate absorption coefficient, low bulk density and friable consistence. These soils are widely distributed in the Hokkaido, Tohoku, Kanto, Tokai, San-in and Kyushu regions. This soil great group has six soil groups.

D1 Regosolic Andosols

Soils belonging to the Andosol great group and with vitric soil materials $25 \mathrm{~cm}$ or more within $50 \mathrm{~cm}$ of the mineral soil surface.

D2 Gleyed Andosols

Soils belonging to the Andosol great group and with a gley horizon or an organic layer and upper boundaries within $50 \mathrm{~cm}$ of the mineral soil surface.

D3 Wet Andosols

Soils belonging to the Andosol great group, which have a mottled horizon typically featuring tubular iron mottles formed under the fluctuation of groundwater, or a marbled horizon formed under the influence of stagnant water and upper boundaries within $50 \mathrm{~cm}$ of the mineral soil surface.

D4 Fuluvic Andosols

Generally weathered volcanic ash soils under virgin forests are not black, despite being rich in organic matter.
D5 Non-allophanic Andosols

The existence of a special variety of Andosols mainly comprising crystalline clay, high in exchange acidity (Y1) and strongly acidic has been confirmed.

D6 Allophanic Andosols

These soils are the central concept of Andosol great group and are characterized by the dominance of allophane and imogolite formed by the weathering of volcanic ash under well-drained conditions and accumulated humus.

\section{E Dark Red soils}

These soils are "1) soils having a dark red subsurface soil, or 2) limestone-derived soils of which the $\mathrm{pH}\left(\mathrm{H}_{2} \mathrm{O}\right)$ is 5.5 or more, or the percentage base saturation is 50 or more throughout the subsurface soil". These soils occur in hills and limestone terraces, and are mainly used as upland crop fields and orchards. This soil great group has three soil groups.

E1 Calcaric Dark Red soils

These soils are developed from limestone or calcaric soil material, with a $\mathrm{pH}\left(\mathrm{H}_{2} \mathrm{O}\right)$ of 5.5 or more, or percentage base saturation of 50 or more throughout the subsurface soil.

\section{E2 Dystric Dark Red soils}

These soils have a $\mathrm{pH}\left(\mathrm{H}_{2} \mathrm{O}\right)$ of less than 5.5, or the percentage base saturation is less than 50 in at least one layer of the subsurface soil.

E3 Eutric Dark Red soils

These soils are developed mainly from ultrabasic rock (e.g. peridotite, serpentinite), and the $\mathrm{pH}\left(\mathrm{H}_{2} \mathrm{O}\right)$ is 5.5 or more throughout the subsurface soil.

F Lowland soils

Soil groups of fluvial, lacustrine and marine, alluvial plains. These soils are widely found in flood plain, deltas and tidal flats. This soils are used widely as paddy field. This soil great group has five soil groups, "Lowland Paddy soils", "Gley Lowland soils", "Gray Lowland soils", "Brown Lowland soils", and "Regosolic Lowland soils".

F1 Lowland Paddy soils

In principle irrigation water aquic and groundwater aquic soils are divided in this system, and irrigation water aquic soils first key out from the lowland soil group. Paddy soils developed under the influence of irrigation water exhibit horizon differentiation due to eluviation and accumulated iron and manganese, and/or have a thick, gray subsurface horizon.

F2 Gley Lowland soils

These soils are defined as "Lowland soils with a nearly permanently saturated gley horizon with its upper boundary within $50 \mathrm{~cm}$ of the mineral soil surface".

F3 Gray Lowland soils

These soils are defined as "lowland soils with a mottled horizon formed under seasonal saturation of groundwater with its upper boundary within $50 \mathrm{~cm}$ of the 
mineral soil surface".

F4 Brown Lowland soils

These soils are "soils of alluvial plains, of which the subsurface horizon is yellowish brown-colored with no influence of ground water within $50 \mathrm{~cm}$ of the surface and no or weak influence of irrigation water".

F5 Regosolic Lowland soils

These soils are "unweathered clastic sediments in lowlands". Normally these soils are gray-colored (color of clastic materials) and have no rusty mottles because of the lack of free iron.

G Red-Yellow soils

These soils are "terrestrial soils that have an argic or cambic horizon with Red-Yellow property“. These soils are distributed in Pleistocene terraces, hills and low mountains and proliferate in southwestern Japan and southwestern islands. Generally these soils are strongly acidic, and poor in bases. Land use is upland crop fields, orchards and paddy fields. This soil great group has two soil groups, "Argic Red-Yellow soils", and "Cambic Red-Yellow soils".

G1 Argic Red-Yellow soils

These soils are Red-Yellow soils which have an argic horizon.

G2 Cambic Red-Yellow soils

These soils are Red-Yellow soils which have a cambic horizon.

H Stagnic soils

These soils are "ill-drained upland soils having aquic properties with its upper boundary within $50 \mathrm{~cm}$ of the mineral soil surface". This soil great group includes two soil groups, "Stagnogley soils" and "Pseudogley soils".

H1 Stagnogley soils

These soils are "ill-drained upland soils having a stagnant water gley horizon $10 \mathrm{~cm}$ thick or more, which does not disappear year-round with its upper boundary within $50 \mathrm{~cm}$ of the mineral soil surface". One type of these soils is found in the slight depressions in Pleistocene terraces where soils are permanently saturated with stagnant water due to the constant supply of water from surrounding higher lands. The other type are man-made terrace paddy soils in the mountainous and hilly areas facing the Japan Sea, where soils are kept artificially flooded, not only during the rice growing season, but also the off-season because of the high rain and snowfalls.

H2 Pseudogley soils

These soils are "ill-drained upland soils formed under seasonal saturation with stagnant water, that have a gray-colored horizon with rusty iron mottles of any shape, with its upper boundary within $50 \mathrm{~cm}$ of the mineral soil surface". These soils are widely distributed in Hokkaido and Tohoku regions. Land use includes upland crop fields and paddy fields, while in Hokkaido, a considerable portion is also used as grassland. Genetically these soils are those which have become gray due to seasonal saturation.

I Brown Forest soils

These soils are widely distributed in mountains and hills, but also occur in Pleistocene terraces in the northeast region. The A horizons are often dark-colored, while the subsurface soil is yellowish-brown. The color is yellowishbrown with a hue yellower than 5YR, value of 3 or more and chroma of 3 or more but less than 6 and also including value/chroma of $3 / 6,4 / 6$. These soils are generally low in base saturation and acidic in reaction, and are mainly used as forests, upland crop fields, pastures and orchards. This soil great group has only one soil groups, "Brown Forest soils". J Regosols

These soils are underdeveloped soils that have no diagnostic horizon except Mollic epipedon. This soil great group has four soil groups, "Volcanogenous Regosols", "Sandy Regosols", "Lithosols", and "Terrestrial Regosols" J1 Volcanogenous Regosols

"Soils in which the cumulative thickness of unweathered pyroclastic materials with phosphate absorption coefficient of less than 300 and organic carbon contents of less than $3 \%$, is $25 \mathrm{~cm}$ or more within $50 \mathrm{~cm}$ of the mineral soil surface".

J2 Sandy Regosols

These soils are coarse-textured soils. These soils are widely found mainly in slightly elevated areas along the sea coast, such as sand dunes, sand bars, sand banks and spits. The land involved is mostly idle, but partly used to break the wind and upland crop fields. In places the lands are also intensively used to grow vegetables, flowers and fruits.

J3 Lithosols

These soils are "residual soils that have 1) a bedrock with an upper boundary within $30 \mathrm{~cm}$ of the mineral soil surface, or 2) a skeletal layer within $30 \mathrm{~cm}$ of the surface which is underlain by bedrock which appears within $60 \mathrm{~cm}$ of the surface".

J4 Terrestrial Regosols

Immature soils of mountains, hills and Pleistocene terraces. These soils are defined as "1) soils with a gravel layer within $30 \mathrm{~cm}$ of the surface but with no bedrock within $60 \mathrm{~cm}$ of the surface, or 2) unweathered soils showing the color of parent rock (or materials) due to the lack of free iron oxides liberated by weathering.

(2) Lower categories: Soil subgroups and Soil series groups

In the Soil subgroups category, the notable morphological features, transitional status to the other soil group, subdivision of aquic conditions etc. are distinguished. Examples of the terms and meanings used in the Soil subgroups are shown in Table 3. In the Soil series groups category, soil texture, depth of the gravel layer, humic surface horizon, and other characteristics affecting productivity and environmental functions of soils are distinguished (Table 4). 


\section{Future development of soil classification in Japan}

The Comprehensive Soil Classification System of Japan, First Approximation contains four category levels, which renders the system usable for both general outlines and detailed description, and to create soil maps and soil information on various scales. However, some unsolved

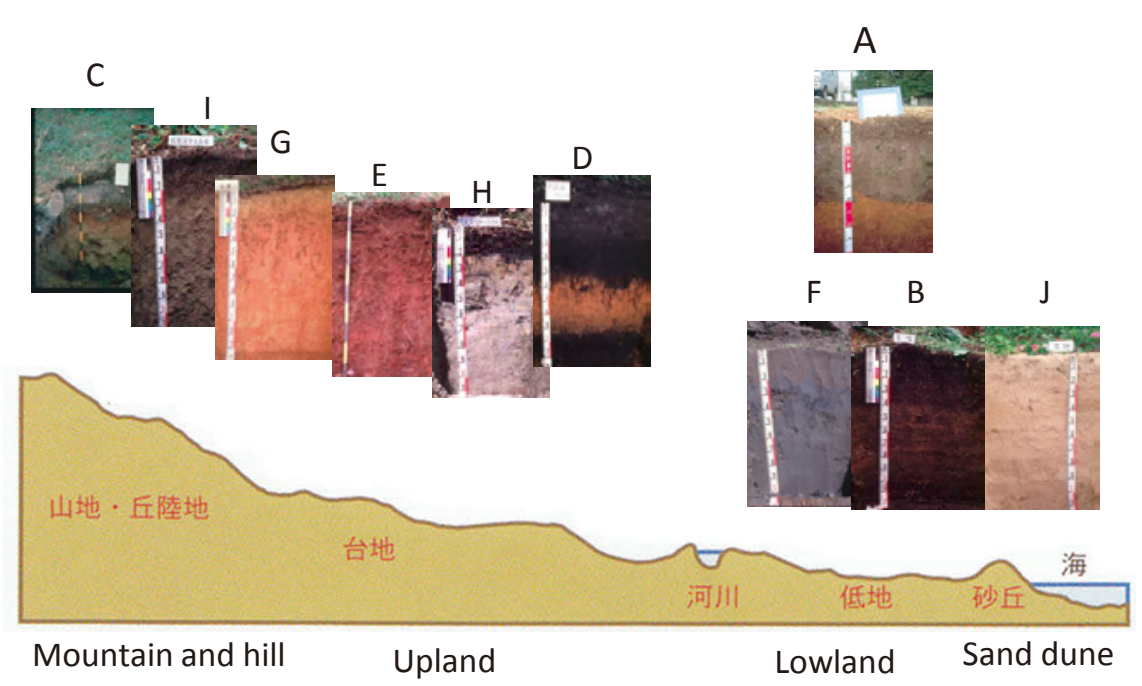
A. Man-made soils
B. Organic soils
C. Podzols
D. Andosols
E. Dark Red soils
F. Lowland soils
G. Red-Yellow soils
H. Stagnic soils
I. Brown Forest soils
J. Regosols

Fig. 2. Soil Great Groups of the Comprehensive Soil Classification System of Japan

Table 3. Examples of Terms and Their Meanings Used for Soil Subgroups

\begin{tabular}{|c|c|c|}
\hline Soil Subgroups & Connotation & Soil groups \\
\hline Strong & Strongly reduced from the surface layer & Gley lowland soils \\
\hline Mottled & $\begin{array}{l}\text { Hav } 5 \text { ng gley horizons with iron mottling, within } 25 \mathrm{~cm} \text { of the soil } \\
\text { surface. }\end{array}$ & Gley lowland soils \\
\hline Aquic & $\begin{array}{l}\text { Having a layer with groundwater aquic properties or gley horizon, } \\
\text { within } 75 \mathrm{~cm} \text { of the soil surface. }\end{array}$ & \\
\hline Groundwater-aquic & $\begin{array}{l}\text { Having a layer, } 10 \mathrm{~cm} \text { or more thick with groundwater aquic proper- } \\
\text { ties or gley horizon, within } 75 \mathrm{~cm} \text { or more of the soil surface. }\end{array}$ & Pseudogley soils \\
\hline Epi-gleyed & Having an inverted gley horizon & $\begin{array}{l}\text { Lowland Paddy soils, Gray } \\
\text { Lowland soils }\end{array}$ \\
\hline Epi-gray & $\begin{array}{l}\text { Having a layer with groundwater aquic properties, within } 25-50 \mathrm{~cm} \\
\text { of the soil surface. }\end{array}$ & Gley lowland soils \\
\hline Gleyed & Having a gley horizon, within $75 \mathrm{~cm}$ of the soil surface. & Gray Lowland soils \\
\hline Pseudogleyic & Having a Pseudogleyic horizon, within $75 \mathrm{~cm}$ of the soil surface. & Podzols, Red-yellow soils \\
\hline Epi-pseudogleyic & Having a Pseudogleyic horizon, within $50 \mathrm{~cm}$ of the soil surface. & Podzols \\
\hline Endoaeric & $\begin{array}{l}\text { Having a yellowish-brown layer, } 15 \mathrm{~cm} \text { or more thick, within } 75 \mathrm{~cm} \\
\text { of the soil surface. }\end{array}$ & Lowland Paddy soils \\
\hline Aeric & Having a layer with no mottles, within $30 \mathrm{~cm}$ of the soil surface. & Pseudogley soils \\
\hline Anthraquic & Having iron accumulation horizon & \\
\hline Protoanthraquic & Having a gray surface horizon with iron mottles & Brown lowland soils \\
\hline Irrigation water-aquic & Having an inverted gley horizon & Stagnogley soils \\
\hline
\end{tabular}


Table 4. Terms and Their Meanings Used for Soils Series Groups

\begin{tabular}{|c|c|c|}
\hline Code & Series Group & Connotation \\
\hline p1 & Lithic & Having a lithic contact within $60 \mathrm{~cm}$ of the soil surface \\
\hline $\mathrm{p} 2$ & Skeletal & Having a gravel layer within $60 \mathrm{~cm}$ of the soil surface \\
\hline p3 & Petric & Having a hard pan within $60 \mathrm{~cm}$ of the soil surface \\
\hline $\mathrm{t} 1$ & Fine-textured & The texture of the subsurface horizon is $\mathrm{HC}, \mathrm{SiC}, \mathrm{KiC}, \mathrm{SC}, \mathrm{SiCL}, \mathrm{CL}$, or SCL. \\
\hline $\mathrm{t} 2$ & Medium-textured & The texture of the subsurface horizon is SiL, L, or FSL. \\
\hline $\mathrm{t} 3$ & Coarse-medium-textured & The texture of the subsurface horizon is SiL, L, FSL. CoSL, LS, or S. \\
\hline $\mathrm{t} 4$ & Coarse-textured & The texture of the subsurface horizon is CoSL, LS, or S. \\
\hline $\mathrm{v} 1$ & Low-humic & Having no Humic surface horizon \\
\hline v2 & Cumulic & Having a (High-)Humic surface horizon, $50 \mathrm{~cm}$ or more thick. \\
\hline v3 & High-humic & Having a High-humic surface horizon. \\
\hline $\mathrm{v} 4$ & Humic & Having a Humic surface horizon \\
\hline v5 & Thapto-humic & Having a Thapto-humic horizon, within $50 \mathrm{~cm}$ of the soil surface. \\
\hline w1 & Epi-mineralic & Having a mineral soil layer $10 \mathrm{~cm}$ or more thick at the surface. \\
\hline w2 & Endomineralic & Having a mineral soil layer $25 \mathrm{~cm}$ or more thick, within $75 \mathrm{~cm}$ of the soil surface. \\
\hline w3 & Thapto-peaty & Having a peat layer, $25 \mathrm{~cm}$ or more thick, within $75 \mathrm{~cm}$ of the soil surface. \\
\hline w4 & Endofluvic & Having a layer of fluvic material, $25 \mathrm{~cm}$ or more thick, within $75 \mathrm{~cm}$ of the soil surface. \\
\hline w5 & Thapto-andic & $\begin{array}{l}\text { Having a layer of andic soil material, } 25 \mathrm{~cm} \text { or more thick, within } 75 \mathrm{~cm} \text { of the soil } \\
\text { surface. }\end{array}$ \\
\hline $\mathrm{x} 1$ & Aquic & $\begin{array}{l}\text { Having a layer with groundwater aquic properties or gley horizon, within } 75 \mathrm{~cm} \text { of the } \\
\text { soil surface. }\end{array}$ \\
\hline $\mathrm{x} 2$ & Fibric & Fibric peat material is dominated within $50 \mathrm{~cm}$ of the soil surface \\
\hline $\mathrm{x} 3$ & Mollic & Having a Mollic horizon \\
\hline $\mathrm{x} 4$ & Non-allophanic & $\begin{array}{l}\text { Having a layer of Non-allophanic andic properties, } 25 \mathrm{~cm} \text { or more thick, within } 50 \mathrm{~cm} \text { of } \\
\text { the soil surface. }\end{array}$ \\
\hline y1 & Typic & Others \\
\hline
\end{tabular}

problems and room for development remain. To adopt more detail to agricultural productivity and/or new environmental issues such as radioactive contamination, surface soil characterization, such as clay mineralogy, nutrient status, characteristics of organic material, etc. will be effective. Moreover, to provide sufficient information on nutrient or pollutant dynamics on a watershed scale, deep soil (more than $1 \mathrm{~m}$ depth) characterization could be added to soil classification that treats the $1 \mathrm{~m}$ soil profile.

\section{References}

Akagi, I. et al. (2003) Pedological properties of Red-Yellow soils (paleo-Red soils) in southern Kyushu. Jpn. J. Soil Sci. Plant Nutr., 74, 623-630 [In Japanese and English summary].

Araki, S. (1993) Comparative study of Kunigami Mahji and Feichisha Soils in Okinawa Islands Among Red-Yellow Soils of the World. Pedologist, 37, 113-125 [In Japanese].

Cultivated soil Classification Committee 1995: Classification of Cultivated Soils in Japan Third Approximation, Miscellaneous Publication of the National Institute of Agro-Environmental Sciences, No. 17, 1-79 [In Japanese].

FAO, ISRIC and ISSS (1998) World Reference Base for Soil Resources (WRB). FAO, World Soil Resources Reports, 84, 1-88, Rome.

FAO, ISRIC and ISSS (2006) World Reference Base for Soil Resources 2006, A framework for international classification, correlation and communication. FAO, World Soil Resources Reports, 103, 1-128, Rome.

Forest soil division (1976) Classification of forest soil in Japan (1975), Bull. Gov. For. Exp. Sta. No. 280, 1-28 [In Japanese and English summary].

Hamazaki, T. (1993) Moisture Regime and Its Pedogenic Roles in Anthraquic Paddy Soils. Pedologist, 37, 15-27 [In Japanese 
and English summary].

Honna, T. et al. (1998) A Simple Procedure to Determine Melanic Index that is Useful for Differentiating Melanic from Fulvic Andisols. Pedologist, 32, 69-78.

Imaya, A. et al. (2010) Proposal for advanced classification of brown forest soils in Japan with reference to the degree of volcanic ash additions. Soil Sci. Plant. Nutr., 56, 454-465.

Kamoshita, Y. (1940) The soil types of the TSUGARU plain, Aomori prefecture, Nippon, Journal of Imp. Agr, Exp. Sta., III-3, 401-420 [In Japanese and English summary].

Kanno, H. (1957) Fundamental soil profiles of inorganic paddy soils. Japanese Journal of Soil Science and Plant Nutrition, 27, 393-396 [In Japanese].

Kato, Y. (1984) Kuroboku soils and related soils. Pedologist 28, 164-175 [In Japanese].

Kyuma, K. (2004) Paddy soil science. Kyoto University Press, 1-280, Kyoto.

Matsui, T. et al. (1961) A tentative scheme of classification for paddy soils on the alluvial plain, with special reference to the soil survey around Shizuoka City, Pacific coast of central Japan. Pedologist, 5, 80-91 [In Japanese and English summary].

Matsui, T. (1964) An objection to the so-called "zonality" of the Red soils in Japan, and a proposal of the Yellow-brown Earth as a newly established genetic soil type. Pedologist, 8, 42-48 [In Japanese and English summary].

Matsui, T. \& Kato, Y. (1962) Notes on paleopedology of red soils in Japan. The Quat. Res. (Daiyonki-kenkyu), 2, 161-179 [In Japanese and English summary].

Mitsuchi, M. (1974) Pedogenic Characteristics of Paddy Soils and Their Significane in Soil Classification. Bulletin of the National Institute of Agricultural Sciences, B-25, 29-115 [In Japanese and English summary].

Nagatsuka, S. (1975) Genesis and classification of YellowBrown Forest soils and Red soils in southwest Japan. Bull. Natl. Inst. Agr. Sci., Ser. B, No. 26, 133-257 [In Japanese and English summary].

Nagatsuka, S. \& Maejima, Y. (2001) Dating of soils on the raised coral reef terraces of Kikai Island in the Ryukyus, Southwest Japan: With Special reference to the age of Red-Yellow soils.
The Quat. Res. (Daiyonki-kenkyu), 40, 137-147.

Obara, H. et al. (2011) Comprehensive Soil Classification System of Japan, First Approximation, Bulletin of National Institute for Agro-Environmental Sciences, No. 29, 1-73.

Ohmasa, M. (1951) Studies of Beech forest soils. Forest soils of Japan (Rep. Gov. Forest Ex. St.), 1, 243.

Ohmasa, M. et al. (1955) Studies of red soils of Japan I, Red soils of Niigata Prefecture. Journal of Japanese Forest Society, 37, 140-142 [In Japanese and English summary].

Saigusa, M. et al. (1980) Plant root growth in acid Andosols from northeastern Japan. 2 Exchange acidity Y1 as a realistic measure of aluminum toxicity potential. Soil Sci., 130, 242245.

Shoji, S. et al. (1985) Properties of nonallophanic Andosols from Japan. Soil Sci., 140, 264-277.

Soil Survey Staff (1990) Keys to Soil Taxonomy, SMSS Technical Monograph No. 19 Fourth Edition, Virginia Polytechnic Institute and State University, Virginia.

Soil Survey Staff (1999) Soil Taxonomy, A Basic System of Soil Classification for Making and Interpreting Soil Surveys, Second Edition. USDA, NRCS, Agriculture Handbook, No. 436, 1-869, Washington, DC.

Soil Survey Staff (2010) Keys to Soil Taxonomy, Eleventh Edition. USDA, NRCS, 1-338, Washington, DC.

Takata Y. et al. (2010) Locating the taxonomical position of argic horizons and cambic horizons in Japanese Red-Yellow soils, Pedologist, 54, 11-20

The Fourth Committee for Soil Classification and Nomenclature, The Japanese Society of Pedology (2003) Unified Soil Classification System of Japan - 2nd Approximation (2002) . Hakuyusha, 1-90, Tokyo [In Japanese].

Uchiyama, N. (1949) Morphology of paddy soils, Chikyu shuppan, Tokyo [In Japanese].

Wada, K. (edited) (1986) Ando Soils in Japan, Kyushu University Press, 1-276, Fukuoka, Japan.

Yamazaki, K. (1960) Studies on the pedogenetic classification of paddy soils in Japan, Bulletin of Agricultural experimental station of Toyama prefecture, Special issue No. 1, 1-98 [In Japanese]. 